\title{
Divergence of potential state-level performance measures to assess transportation and land use coordination
}

\author{
John S. Miller \\ Virginia Transportation Research Council $^{a} \quad$ Virginia Transportation Research Council $^{\text {b }}$
}

\begin{abstract}
Although performance measures encourage agreement in other disciplines, measures for state transportation and land use may engender disagreement among stakeholders. A literature review and a survey of 25 states and three metropolitan planning organizations identified 41 such measures. No single measure best quantifies effective coordination because this coordination supports potentially conflicting goals, such as better access management and increased local autonomy. Further, when measures are computed under four benevolent scenarios that each generate the support of some stakeholders-reduced transit costs, reduced congestion, increased local autonomy, and increased compact development-some performance measures indicate improvement and others do not.
\end{abstract}

Keywords: Performance Measurement; Measures of Effectiveness; Transport and Land Use Coordination; Performance Standards

\section{Introduction}

Performance measures, also known as performance indicators, metrics, or measures of effectiveness (MOEs), are variables that indicate the performance of a system with respect to a particular objective. In 2006, Virginia's governor charged Virginia's Transportation Accountability Commission (TAC) with "recommending quantifiable outcome measures...that incorporate effective land use and transportation coordination" (Kaine 2006). Although states and metropolitan planning organizations (MPOs) are using outcome measures for other areas of transportation, at the time the commission was created, specific measures that might be used to assess transportation/land use coordination were unclear.

Although the TAC's charge (Kaine 2006) refers to outcomes, a reading of select literature (Falcocchio 2004; Meyer 2005) raises questions with regard to whether a clear demarcation can be made between outputs (such as miles of roads plowed) and outcomes (such as number of crashes attributable to snow on the road). The example of the former is under agency control, whereas the example of the latter is influenced by external forces. If a region establishes a goal of reducing the amount of land consumed by development and selects transitoriented development (TOD) as one initiative to achieve that

\footnotetext{
a Associate principal research scientist, john.miller@vdot.virginia.gov.

b Public relations and marketing practitioner, linda.evans@vdot. virginia.gov.
}

goal, annual acres of land developed is a viable outcome measure. However, is the amount of TOD created per year also an outcome measure? A "no" answer is supported by the fact that TOD is not the end goal and that some aspects of TOD, such as the amount of land zoned for it, are under agency control. A "yes" answer is supported by the fact that the amount of TOD is influenced by market factors beyond agency control, such as the willingness of developers to supply TOD and the desire of prospective buyers to purchase units. Thus adherence to the term outcome measures might, unfortunately, eliminate potentially viable metrics if survey respondents believed they could not list output measures.

The aforementioned difference between output and outcome measures also suggests that each initiative may have multiple final goals. In the case of TOD, desired outcomes might include reduced land development, reduced fuel consumption, improved air quality, or increased transportation options. Accordingly, the question of interest to Virginia became: What performance measures are states using, or considering using, to evaluate transportation/land use coordination?

To identify such measures, a review of the literature and an open-ended telephone survey of transportation representatives from 25 states were conducted over a six-month period in 2007. The purpose of the research study reported here was to determine whether the identified measures converged toward a single overall goal.

Copyright 2011 John S. Miller and Linda D. Evans.

Licensed under the Creative Commons Attribution - NonCommercial License 3.0. 


\section{Literature review}

Although much literature covers transportation performance measures (Falcocchio 2004; Larson 2005), less exists regarding measures to assess transportation/land use. The literature explores three areas: (1) the need to consider transportation and land use jointly when assessing how well a system performs, (2) goals that such consideration should accomplish, and (3) implementation efforts in the United States.

\subsection{The necessity of considering transportation and land use together}

Performance areas reflecting both land development and transportation infrastructure were suggested by Ewing (1993): traffic congestion (measured as level of service or delay), travel volume (measured as vehicle miles traveled (VMT), number of trips, average trip length, or the gravity model's formulation of accessibility), and "travel opportunity for the transportation disadvantaged" (which may be measured as mode split). Later, Singa et al. (2004) identified the ratio of jobs to housing for specific parts of a region, the proportion of workers who commute into a jurisdiction from elsewhere, and the mode of transportation used by those workers as metrics directly relevant to transportation/land use coordination. Land use and transportation were jointly addressed by El-Geneidy and Levinson (2006) who, for each zone in the Minneapolis-Saint Paul (USA) metropolitan region, found the difference between the number of jobs within 15 minutes travel time in 1990 and in 2000. This calculated difference could have resulted from transportation initiatives (such as better bus service) or from land use actions (such as increased employment); the measure reflects a focus on accessibility (i.e., an "ability to get what one needs," (Handy 2005)) rather than mobility (i.e., the ease with which one moves).

Some researchers, while not specifying which measures must be used, have advocated the development of transportation/land-use coordination indicators as a productive exercise simply because the disparate areas of transportation planning and land use planning need to be joined (Amekudzi et al. 2007). Levy (1994) suggested that the impact of a transportation decision on land development should be considered explicitly because such decisions "shape land use for decades to come." A decade later, reviewers of the UrbanSim land use model (which was integrated with the Wasatch Front Regional Council travel demand model) emphasized the importance of considering the influence of transportation investments on land decisions, which, in turn, affects the demand for the same transportation facilities; resultant metrics were VMT and hours of delay (Waddell et al. 2007). The Michigan Department of Transportation (2006) noted that joint consideration of transportation and land use may overcome barriers, such as a "walkable neighborhood completely surrounded by uses through which the pedestrian cannot walk to get to a transit stop."

Others have emphasized the multidimensional nature of transportation/land use coordination. Levinson and Krizek (2008) noted that although ease of movement is relevant, a more complete perspective combines this mobility component and a component based on the relative attractiveness of the reachable destinations (combining both components yields "accessibility"). Such metrics vary by stakeholder (Levinson and Krizek 2008); a measure of compact development captures one aspect of efficiency (amount of land consumed) but not necessarily the experience of a traveler (such compact development may produce greater congestion, more choices, both, or neither). Thus it is not surprising that cautions have been raised regarding the use of a single measure: a metric based on a street pattern (Krizek 2005) may represent ease of access to local destinations (e.g., shorter blocks and wider sidewalks to facilitate pedestrian travel) and regional destinations; a grid helps auto travel by separating traffic streams and makes transit travel among multiple activity centers much more feasible (Koski 1992). Horner and Mefford (2005) noted that the explanatory power of accessibilitybased measures (such as those produced by the common gravity model application, which are based on the combination of an impedance measure and the cumulative sum of attractions) is limited because the single number does not differentiate between these two factors.

\subsection{Goals of transportation/land use coordination}

Researchers have suggested diverse goals of transportation/land use coordination. One implied goal is that increased coordination should "reduce the level of surprise at new developments," as determining where future developments will occur can be time-consuming (Duthie et al. 2007). Another is the implementation of context-sensitive solutions and hence "policies that fit the character of the community" (Knack 2007). Other goals put forward by researchers include the allocation of emergency response resources based on the expected crashes that particular land uses may generate (Pawlovich et al. 1998) and the avoidance of controversy because of noise (Avery et al. 2006). In an intriguing exception, Staley and Claeys (2005) argued that the evaluation of a proposed land development should not take into account the 
project's impact on community character unless the development infringes on the rights of others.

Goals of transportation and land use interactions at the regional (MPO) level include promoting transit-oriented development, reducing land consumption in general (Volpe National Transportation Systems Center undated), and reducing farmland consumption in particular (Venner Consulting and Parsons Brinckerhoff 2004). Metrics have also been proposed in the context of specific programs: for example, to evaluate the impacts of a vehicle-sharing initiative on land use, suggested measures included the number of users per parking space, vehicle ownership, and the amount of new residential development (Shaheen et al. 2004). Minnesota proposed the use of corridor travel speeds to assess a relatively specific program aimed at protecting arterial highways (referred to as "interregional corridors") where there was a risk that development would lead to increases in the number of traffic signals and thereby reduce operating speeds (Zemotel and Montebello 2002).

Composite measures have also been proposed. One is the "transportation efficiency" of a zone, which is defined as the number of modal options available to travelers and determined by the density of development, mix of land uses, availability of parking, topography of pedestrian facilities, block size, and amount of affordable housing in the zone (Moudon et al. 2005; Washington State Department of Transportation 2006c). Florida's multimodal level of service concept is a "land use and transportation integration measure" with dual goals: to make walking and the use of transit appealing; and to consider the impacts of development on all transportation modes (Guttenplan et al. 2003). The European Union's PROPOLIS initiative aggregates indicators such as tons of carbon dioxide emitted, percentage of land developed, amount of oil consumed, and open space quality into a composite environmental metric; similarly, vehicle delay, traffic injuries, and the percentage of overcrowded households are aggregated into a composite social performance measure (Lautso et al. 2004). Doi et al. (2008) developed a quality of life metric based on 16 different indicators such as employment rate, landscape design, the time required to reach hospitals, and the availability of large retail stores and cultural opportunities.

Redress of inequity is the goal of several metrics that capture some aspect of travel impedance between residential areas and potential employment locations. The ratio of jobs to housing has been suggested as a diagnostic instrument to identify zoning policies that inhibit short commutes (Peng 1997). Such policies include the prohibition of accessory dwelling units and small convenience stores in residential neighbor- hoods (Atlanta Regional Commission 2002), minimum lot size requirements (Levine 1998), and growth restrictions (e.g. Cervero 1996).

Equity of service has also received attention. Horner and Mefford (2005) estimated the number of transit-accessible opportunities per worker as a function of industry and, after stratifying by ethnicity, found that lower-paid workers had fewer opportunities. The researchers modified this metric to compute the number of accessible employment opportunities by zone (without normalizing by the number of workers in the zone); the modified metric provided a neighborhood accessibility measure, which indicated that minority neighborhoods in the study area were not as well served as "non-Hispanic, white neighborhoods" in terms of transit access to employment opportunities. Across the entire study area, the authors found that for some groups a smaller number of accessible jobs per worker existed in the lower paying retail industry than in the higher paying professional industry, suggesting ways to target specific investments, such as reverse commute initiatives or other transit services that appeal to specific sets of riders (see Levinson and Krizek 2008). Handy (2005) compared the number of employment opportunities that could be reached within specified time intervals using various travel modes from economically disadvantaged and prosperous neighborhoods.

\subsection{State implementation efforts}

States have instituted statutes, practices, and incentives to achieve policy goals regarding where development should be targeted. Maryland and New Jersey have tried to target growth. Maryland's priority funding areas guide state infrastructure investments such as major non-toll construction projects (Lewis et al. 2009). Although some priority areas are established by the state, others may be designated by counties if certain criteria are met (e.g., for undeveloped areas, sewer service and a density of at least 3.5 dwellings per acre must be expected); a related evaluation metric is the number of acres developed within such areas relative to the acres developed outside such areas (Lewis et al. 2009; Orski 2009). New Jersey's State Development and Redevelopment Plan (New Jersey State Planning Commission 2001) identifies areas where various types of land development are desired. The plan does not carry the force of law but is intended to inform actions of other governmental units. The plan tracks a variety of transportation metrics (e.g., per-capita VMT), land use factors (e.g., acreage set aside as open space), and indicators of intergovernmental coordination (e.g., the extent of agreement between city/county plans and the state plan). 
States have also established initiatives to achieve specific policy goals. California established a public incentive program for regions to address imbalances between jobs and employment opportunities (Armstrong et al. 2001; California Department of Housing and Community Development 2007). Another incentive program in Massachusetts permits localities to raise real estate taxes by referendum in order to preserve open space and increase the amount of housing; the state may match up to 100 percent of these taxes (Courchesne 2004). States have also undertaken specific initiatives to align transportation infrastructure and development, such as managing access to interchanges (Vermont), constructing an innovative "cap" on a bridge that accommodates development, thereby connecting rather than bisecting a community (Ohio), and encouraging compact development (Oregon's Transportation and Growth Management Program; American Association of State Highway and Transportation Officials 2009). Another policy goal is to encourage direct consideration of transportation land use impacts: for example, Virginia requires that localities, which control land development, submit comprehensive plans, rezoning requests, and site plans to the state department of transportation for comment (Virginia Department of Transportation 2008). The comments are advisory and thus do not restrict the authority of localities to manage land development (Virginia Department of Transportation 2010).

\section{Survey of states}

\subsection{Methodology}

A telephone survey of DOT planners representing 25 states was conducted. The states were drawn from different quadrants of the United States. The sample was also diverse in terms of per-capita VMT: of the 10 states with the lowest percapita VMT (Lave 2006), six (Arkansas, Illinois, New York, New Jersey, Rhode Island, and Washington) were included; of the 10 states with the highest per-capita VMT, five (Mississippi, Missouri, New Mexico, Oklahoma, and Vermont) were included. Emphasis was placed on surveying state DOT representatives, although comments from the survey respondents led to the inclusion of representatives of select MPOs for additional insights.

The survey methodology consisted of four steps:

1. Review literature that suggests potential measures that the state DOT might use to measure transportation/land use coordination. Examples included the state's long-range transportation plans, annual reports, or lists of measures.

2. Examine the state DOT's website to identify an interviewee who might have an interest in this topic. This examination was easiest if the website had a section describing planning-related metrics or the importance of transportation/land use coordination. Alternatively, the DOT's planning or environmental section was contacted.

3. Contact the potential interviewee and ask if he or she, or someone he or she could recommend, could discuss metrics the state is using or considering to assess transportation/land use coordination. In some cases, it was most productive (in terms of obtaining responses) to email a potential contact and then follow up with a telephone interview; in other cases it was more productive to talk first by telephone to introduce the survey, send a cover letter, and then continue to correspond by telephone or email. Two sample survey instruments are shown in Figure 1. Due to concerns that sending a uniform survey to a mass of states might not elicit a high response rate as the target audience of planners in state DOTs is exposed to a large number of surveys, every effort was made to tailor the survey questions to each DOT using information about the DOT and a combination of telephone calls, emails and faxes was used to obtain a response. Thus, a survey response could arrive in the form of a telephone call, an email that directly answered the question, an email that referred the investigator to another contact or a particular reference document, or some combination thereof.

4. Provide additional information to the respondent or seek clarification as necessary. If a telephone interview was conducted or if the interviewee's response included a suggested report for further reading, a summary of the conversation or indicators gleaned from the report was provided to the respondent. Each interviewee was eventually given a summary of states' responses, and a few of the respondents provided additional clarification at that stage. In some states, information from more than one respondent was obtained.

The steps were iterative. Representatives from Minnesota, Oklahoma, Rhode Island and Utah suggested additional contacts, which led to the inclusion of two MPOs (the Wasatch Front Regional Council and the Twin Cities Metropolitan Council) and one statewide agency (the Rhode Island 
Dear M s.

When you have a couple of minutes, I wanted to give you a call regarding any performance measures that (insert state name) may use to assess land use transportation coordination.

The reason for my open-ended question is that $I$ have been asked to summarize how several states measure progress toward coordinated transportation and land use. The summary, in turn, may be of interest to Virginia's

Transportation Accountability Commission which has a responsibility of identifying "quantifiable outcome

measures ... that incorporate effective land-use and transportation coordination."

I have followed some of the developments in (insert state name) (although I am definitely not an expert), and your state's website already has some very useful information related to land use and transportation coordination, such as the evolution of the concurrency statutes, the land use/transportation case studies conducted for the Strategic Intermodal System (SIS), and the performance measures used by the State Transportation Commission.

However, there are likely other aspects to measuring effective transportation/land use coordination in use by (insert state name) that I simply am not aware of. Would there be a good time I could contact you to discuss?

Thanks for your assistance,

John Miller, Virginia Transportation Research Council

Dear M

I left a message on your phone this morning, but I promised to put my request in writing. I am hoping that you can point $m e$ in the right direction on this request:

A re there any performance measures that (insert state name) is using, or is considering using, to evaluate transportation and land use coordination?

The reason for my open-ended question is that Virginia has a Transportation Accountability Commission that has been charged with "identifying quantifiable outcome measures... that incorporate effective land-use and transportation coordination." The Commission has asked how other states measure progress toward coordinated transportation and land use. I presented some initial findings to the Commission in $\mathrm{May}$, based on just a dozen states, and because of the interest in the topic would like to include additional states in the survey. (I can provide a short summary or detailed presentation of response from other states if that is helpful, but I did not want to unnecessarily overload your mailbox with attachments!)

(Before contacting you I saw that your website has some information on this topic; for example, the Statewide Intermodal Long Range Plan mentions connections between transportation and land use, and one piece of literature mentions noise and land use compatibility. However, while those sources are helpful, I still would want to speak with a representative of (insert state name) to ensure that I had understood those sources.)

Is there a time that I could call you to discuss?

Thank you for your help,

John Miller, Virginia Transportation Research Council, 434-293-1999

Figure 1: Sample survey instruments. 
Statewide Planning Program). One respondent initially indicated that the state did not have explicit performance measures at present and later, after seeing a summary of metrics, provided potential measures (but clarified that none explicitly addressed transportation/land use coordination). Two respondents who had given explicit transportation/land use coordination measures noted upon their review of the results from other states that they could suggest additional metrics. The customization and iterative nature of this approach meant the survey was conducted over a four-month period.

\subsection{Survey results}

Responses to the survey were obtained from 25 states. Respondents from seven states (Arkansas, Illinois, Mississippi, New Jersey, Ohio, Oklahoma and South Dakota), provided no performance indicators for transportation/land use coordination, although several provided useful insights noted elsewhere in this paper.

Respondents from seven of the remaining 18 states, (Arizona, Florida, Maryland, New Mexico, North Carolina, Vermont and Washington) provided no performance indicators for transportation/land use coordination, but either the respondent or the literature from the state suggested measures that might potentially be used to assess such coordination. Thus, 11 states (California, Kansas, Maine, Michigan, Minnesota, Missouri, New Hampshire, New York, Oregon, Rhode Island and Utah) had a measure expressly designed for evaluating transportation/land use coordination.

In eight of the 11 states with a performance measure, it appeared that the measure had either been used in the past and was no longer in use, was proposed for future use, or was in development. In the three remaining states (Missouri, New York and Oregon), there appeared to be at least one measure currently in use that was explicitly used to assess coordination.

\section{Method of analysis to determine convergence of goals}

A two-step process was used to determine whether the measures identified in the literature review and in the survey of states converged toward a single goal:

1. Link each measure identified in the literature review and the survey of states and MPOs to a specific goal of transportation/land use coordination.

2. Determine whether the identified measures converge toward a single unifying goal. It was hypothesized that al- though the measures were diverse, they might all represent different dimensions of the same goal. (For example, it could be argued that the two metrics of crash rate and number of near-misses are unified by a goal of improving safety.) To determine whether the measures converged, four scenarios were developed. Each has the support of a particular group of stakeholders. Then, for each measure, the extent to which the four scenarios moved the measures in a similar direction was assessed, thereby indicating the degree of consistency among the measures.

\subsection{Linkage of performance measures to goals}

Each measure identified in the literature review was placed in the context of one of seven specific goals of transportation/land use coordination:

1. Increase the number of transportation options (use modal data).

2. Increase the number of transportation options (do not use modal data).

3. Improve the quality of existing transport options.

4. Improve public services or economic growth.

5. Protect or manage corridors.

6. Align state and local efforts.

7. Reduce land consumption (and other environmental measures).

These seven goals were developed in an iterative fashion. Five were developed after obtaining measures from 12 states and three MPOs. As information was obtained from additional states, it became necessary to add goal 4 (improve public services or economic growth) and to combine what were formerly two goals into what is now goal 5 (protect or manage corridors). The diversity of measures that fell into a former general goal of "improving transportation" suggested that that goal could be divided into goals 1, 2, and 3 .

In some cases, this step was straightforward: for example, the New Hampshire respondent gave a measure of "percent of interregional corridor miles with corridor management/land use plans," which could be linked to goal 5 (corridor management) with a high degree of certainty. In other cases, more effort was necessary. For example, California's respondent noted "the three Es" (economy, environment, and equity) and 
referred the authors to the California Transportation Plan (California Department of Transportation 2006). The plan listed several metrics, such as percentage of workers within 15 minutes of employment, under the goal of "improving travel choices." Accordingly, the authors linked those measures to goal 2, but clearly other linkages were feasible.

Not all stakeholders might view the seven goals as equally worthwhile. For example, some might argue that goals 1, 2 and 5, which emphasize the ability to move within the network, should be eschewed in favor of goals that assess the ease with which destinations can be reached. From this perspective, metrics based on access to centers or the ability to move from one destination to another might be preferred to mobility-oriented measures such as minutes of delay.

\subsection{Determination of goal convergence under four scenarios}

The four scenarios used to determine goal convergence were as follows:

1. Compact development, marketing efforts, zoning policies and new technologies for cleaning brownfield sites result in a higher proportion of homes and businesses being placed in the central business district and infill areas.

2. Congestion reduction. New technologies allow vehicles to be spaced much more closely together, thereby reducing congestion in the short term.

3. Reduced transit costs. New technologies reduce the maintenance costs for existing transit systems and the capital costs for new transit systems.

4. Local autonomy. A large sum of money is made available to localities to invest in land acquisition (e.g., for the preservation of rural areas, or to purchase right-ofway for transportation infrastructure) or transportation acquisition (e.g., for the purchase of additional highway or transit infrastructure, or to support additional maintenance of highways or transit systems). Such a scenario might also appeal because it can address the cited problem (Vanka et al. 2005) of one agency controlling land development and another agency controlling transportation investments.

The four scenarios were chosen because they each appear to have a different supporting constituency; that is, stakeholders who favor greater local autonomy are not necessarily the same stakeholders who favor increased compact development. The scenarios also reflect different emphasis areas both by mode (see scenarios 2 and 3 ) and by objective (see scenarios 1 and 4). Each scenario is designed to include initiatives taken or influenced by a state DOT.

\section{Potential performance measures and linkage with goals}

\subsection{List of performance measures and linkage with goals}

Table 1 lists the 41 potential measures and the 46 applications of these measures gleaned from the literature and the survey of 25 states and MPOs, and links each metric with one of the seven specific goals of transportation/land use coordination described previously.

The performance measures can be described in terms of their linked goals as follows.

1. Increase the number of transportation options (with use of modal data). Five measures using data on changes in a specific mode supported the goal of providing multiple transportation options (goal 1). Examples include percentage of commuters driving alone to work, number of persons using other (e.g., non-auto) modes other modes, and number of spaces used at park-and-ride facilities.

2. Increase the number of transportation options without use of modal data). Nine metrics that did not use data derived from direct observations of mode use supported goal 1. Examples include miles of bicycle and pedestrian (bike/ped) facilities constructed, percentage of jobs within a particular distance of transit facilities, and ratio of the cost of non-auto travel to automobile travel (where cost is a general function that includes monetary expenditures and travel time).

3. Improve the quality of existing transport options. Three states noted indicators that support qualitative improvement of current transportation options, such as reduction of person-hours of delay, customer satisfaction with transportation options, and difference between actual and ideal travel times. As shown by the indicators from New Hampshire and Arizona, there was overlap between this goal and goal 4.

4. Improve public services or economic growth. Four indicators reflected improved delivery of public or private services, such as cost of fire protection, travel time to schools or reduction in consumer costs (food, clothing goods) per person attributable to interstate highways. 
5. Protect or manage corridors. Six metrics were associated with avoiding conflicts between needed right-ofway and development or with improving the management of existing corridors. One example is the number of jurisdictions that have adopted development regulations protecting land adjacent to airports from development, another is the number of jurisdictions where state and local plans are in agreement regarding how an existing arterial will be managed.

6. Align state and local efforts. One goal of transportation/land use coordination is simply to coordinate state and local efforts as opposed to achieving a specific policy. Examples include the number of locations where transportation/land use coordination studies are undertaken, customer satisfaction with coordination, and the number of transportation projects listed in the region's comprehensive plan.

7. Reduce land consumption (and other environmental measures). Examples include the percentage of jobs or employment in desired urban areas, amount of undeveloped land converted, and comparison of this amount of land with the population growth rate. Environmental measures, such as air pollutant levels or wetlands taken, were also suggested as indicators of the quality of transportation/land use coordination.

\subsection{Caveats regarding list of performance measures}

There are three caveats regarding the list of performance measures shown in Table 1.

1. To facilitate comparisons across states, state-specific terminology was avoided. For example, the difference between actual intercity travel time and the intercity travel time that would result from dividing the straight line distance by the speed limit is referred to by Arizona as the "Intercity Travel Time Connectivity" (Cambridge Systematics, Inc. 2004). Maine uses the term accessibility to mean "the ability to get from one destination to another readily," and since accessibility may have different meanings for different audiences (see Levinson and Krizek 2008, Handy 2005 or Harris 2001 for a detailed treatment of accessibility), the definition, rather than the word, is used in Table 1.

2. Judgment was required to classify these measures. For example, Maine listed a performance measure as "travel time to work" and New Hampshire listed a performance measure as "the ratio of corridor to free flow travel times." Although both reflect transportation system performance, they were placed in different categories as the Maine respondent indicated that the metric assesses the ability to get from one destination to another readily whereas the New Hampshire respondent noted that the metric supports economic vitality. Rhode Island provided four objectives (emphasize growth in development centers, preserve open space, preserve functionality of transportation corridors, and reserve land for transportation use) and two measures (rate of growth of the urbanized area relative to population growth rate and completion of one corridor study per year). Table 1 links the first two objectives with the first measure and the second two objectives with the second measure.

The most difficult classifications were those where an indicator was provided but was not intended to evaluate transportation/land use coordination. For example, Vermont's respondent noted that the state had no metrics directly addressing transportation/land use coordination but referred the authors to the state's performance measures report (Vermont Agency of Transportation 2007). A metric in this report, "the record of mileage for bicycle/pedestrian facilities constructed," was linked by the authors to goal 2 , "increase transportation options," but arguably could support other goals. Maryland's respondent provided no explicit metrics for transportation/land use coordination, but because the state's annual attainment reports emphasized TOD with one goal being to improve air quality (Maryland Department of Transportation 2006), Maryland's measure of tons of volatile organic compounds by region was linked to the goal of improving the environment.

3. The lack of an indicator does not denote a lack of transportation/land use coordination efforts. Examples include Vermont (efforts in stormwater management), Illinois (funds to urban areas to coordinate transportation/land use planning), and the several states involved with access management. 
Table 1: Potential transportation/land use coordination performance measures at a glance.

\begin{tabular}{|c|c|c|c|c|c|}
\hline Goal & & Performance Measure & $\begin{array}{l}\text { State or } \\
\mathrm{MPO}^{\mathrm{ab}}\end{array}$ & Status ${ }^{\mathrm{c}}$ & $\begin{array}{l}\text { Is data collected } \\
\text { explicity to measure } \\
\text { coordination? }\end{array}$ \\
\hline \multirow{7}{*}{$\begin{array}{l}\text { Increase } \\
\text { transportation } \\
\text { options }\end{array}$} & 1. & $\begin{array}{l}\text { Percentage of commuters driving alone to work } \\
\text { (Washington State Department of Transportation } \\
\text { 2006c) }\end{array}$ & WA $(1)$ & Active & No \\
\hline & \multirow[t]{2}{*}{2.} & \multirow{2}{*}{$\begin{array}{l}\text { Number of persons using other (e.g. non-auto) } \text { modes }^{g} \\
\text { (California Department of Transportation 2006; Maryland } \\
\text { Department of Transportation 2006) }\end{array}$} & $\mathrm{MD}(2)$ & Active & No \\
\hline & & & $\mathrm{CA}(3)$ & $\begin{array}{l}\text { Appears not } \\
\text { active }\end{array}$ & Yes \\
\hline & 3. & Number of spaces used at park and ride facilities (Maryland & $\mathrm{MD}(4)$ & Active & No \\
\hline & & $\begin{array}{l}\text { Department of Transportation 2006; Vermont Agency of } \\
\text { Transportation 2007) }\end{array}$ & $\operatorname{VT}(5)$ & Active & No \\
\hline & 4. & $\begin{array}{l}\text { Vehicle miles traveled per capita (North Jersey } \\
\text { Transportation Planning Authority 2005) }\end{array}$ & NJTPA (6) & Active & Possibly \\
\hline & 5. & Travel time and distance to work ${ }^{\mathrm{f}}$ & $\operatorname{ME}(7)$ & Proposed & Yes \\
\hline \multirow{9}{*}{$\begin{array}{l}\text { Increase } \\
\text { transportation } \\
\text { options }\end{array}$} & 6. & $\begin{array}{l}\text { Ability to get from one destination to another readily, } \\
\text { where destinations include jobs, retail and tourist stops, } \\
\text { and transit services }\end{array}$ & $\operatorname{ME}(8)$ & Proposed & Yes \\
\hline & 7. & $\begin{array}{l}\text { Percentage of housing units built by location type (e.g., } \\
\text { rural growth center, developing area, remaining rural } \\
\text { area, developed area) }{ }^{h} \text { (Metropolitan Council 2004, } \\
\text { 2006) }\end{array}$ & TCMC (9) & Active & Yes \\
\hline & 8. & $\begin{array}{l}\text { Percentage of jobs/population within particular distance } \\
\text { of transit or modes available (California Department of } \\
\text { Transportation 2006) }\end{array}$ & $\mathrm{CA}(10)$ & $\begin{array}{l}\text { Appears not } \\
\text { active }\end{array}$ & Yes \\
\hline & 9. & $\begin{array}{l}\text { Miles of bike/ped facilities constructed (Vermont } \\
\text { Agency of Transportation 2007) }\end{array}$ & $\mathrm{VT}(11)$ & Active & No \\
\hline & 10. & Number of routes designated as bicycle facilities & NM (12) & Active & Appears to be No \\
\hline & 11. & Number of attractions within a threshold travel time & OR (13) & Active & Yes \\
\hline & 12. & $\begin{array}{l}\text { Ratio of cost of non-auto travel to cost of auto travel, } \\
\text { where cost includes in-vehicle time, waiting time, and } \\
\text { operator expenditures (Reiff and Gregor 2005) }\end{array}$ & OR (14) & Proposed & Yes \\
\hline & 13. & Access to centers & NJTPA (15) & Proposed & Yes \\
\hline & 14. & Ratio of jobs to housing & $\begin{array}{l}\text { WFRCi }(16) \\
\text { CA }(17)\end{array}$ & Proposed & Yes \\
\hline \multirow{4}{*}{$\begin{array}{l}\text { Improve } \\
\text { quality of } \\
\text { existing transp. } \\
\text { options }\end{array}$} & 15. & $\begin{array}{l}\text { Satisfaction with transportation options (Missouri } \\
\text { Department of Transportation 2007) }\end{array}$ & $\mathrm{MO}(18)$ & Active & No \\
\hline & 16. & Person-hours of delay & NY (19) & Active & Yes \\
\hline & 17. & $\begin{array}{l}\text { Average delay per trip; percentage of person-miles by } \\
\text { LOS }\end{array}$ & \multirow{2}{*}{$\mathrm{AZ}(20)$} & \multirow{2}{*}{ Active } & \multirow{2}{*}{ No } \\
\hline & 18. & $\begin{array}{l}\text { Real intercity travel time minus (straight-line distance } \\
\text { divided by speed limit) }\end{array}$ & & & \\
\hline
\end{tabular}


Table 1: Potential transportation/land use coordination performance measures at a glance.

\begin{tabular}{|c|c|c|c|c|c|}
\hline Goal & & Performance Measure & $\begin{array}{l}\text { State or } \\
\mathrm{MPO}^{\mathrm{a}}\end{array}$ & Status ${ }^{\mathrm{c}}$ & $\begin{array}{l}\text { Is data collected } \\
\text { explicity to measure } \\
\text { coordination? }\end{array}$ \\
\hline \multirow{4}{*}{$\begin{array}{l}\text { Improve } \\
\text { public services } \\
\text { or economic } \\
\text { growth }\end{array}$} & 19. & $\begin{array}{l}\text { Response time for fire, police, and rescue and travel time } \\
\text { for schools }\end{array}$ & $\operatorname{ME}(21)$ & Proposed & Yes \\
\hline & 20. & $\begin{array}{l}\text { Cost of municipal services (fire, police, rescue) and travel } \\
\text { times for schools }\end{array}$ & $\operatorname{ME}(22)$ & Proposed & Yes \\
\hline & 21. & $\begin{array}{l}\text { Reduction in consumer costs attributable to better } \\
\text { transport (Kansas Department of Transportation 2007) }\end{array}$ & KS (23) & Proposed & $\begin{array}{l}\text { Yes, to support } \\
\text { economic growth } \\
\text { (land use) }\end{array}$ \\
\hline & 22. & Ratio of actual corridor travel time to free flow travel time & $\mathrm{NH}(24)$ & Proposed & $\begin{array}{l}\text { Yes, to support } \\
\text { economic vitality }\end{array}$ \\
\hline \multirow{7}{*}{$\begin{array}{l}\text { Protect or } \\
\text { manage } \\
\text { corridors }\end{array}$} & 23. & $\begin{array}{l}\text { Number of jurisdictions that have regulations protecting } \\
\text { land adjacent to airports from development (Washington } \\
\text { State Department of Transportation 2006b) }\end{array}$ & WA (25) & Active & No \\
\hline & 24. & $\begin{array}{l}\text { Miles of roadway for which agreements are in place } \\
\text { (between state DOT and local government) }\end{array}$ & $\mathrm{FL}(26)$ & $\begin{array}{l}\text { Possible } \\
\text { suggestion }\end{array}$ & No \\
\hline & 25. & $\begin{array}{l}\text { Alignment of strategic highway corridors and land use } \\
\text { overlay }\end{array}$ & $\mathrm{NC}(27)$ & $\begin{array}{l}\text { Inferred } \\
\text { suggestion }\end{array}$ & $\begin{array}{l}\text { Not collected } \\
\text { per se (but is goal } \\
\text { of coordinating }\end{array}$ \\
\hline & 26. & $\begin{array}{l}\text { Arterials where access management plan has been } \\
\text { established }\end{array}$ & NM (28) & $\begin{array}{l}\text { Possible } \\
\text { suggestion }\end{array}$ & $\begin{array}{l}\text { transport and land } \\
\text { use.) }\end{array}$ \\
\hline & 27. & $\begin{array}{l}\text { Percentage of interregional corridor miles with corridor } \\
\text { management/land use plans }\end{array}$ & NH (29) & Proposed & Yes \\
\hline & 28. & $\begin{array}{l}\text { Agreements between state and local plans (Minnesota } \\
\text { Department of Transportation 2003) }\end{array}$ & $\mathrm{MN}(30)$ & Inactive & Yes \\
\hline & 29. & $\begin{array}{l}\text { Complete } 1 \text { corridor study per year (Rhode Island } \\
\text { Statewide Planning Program 2004) }\end{array}$ & $\mathrm{RI}(31)$ & Proposed & Yes \\
\hline \multirow{6}{*}{$\begin{array}{l}\text { Align state and } \\
\text { local efforts }\end{array}$} & 30. & $\begin{array}{l}\text { Locations where state and integrated transportation } \\
\text { studies are undertaken (North Jersey Transportation } \\
\text { Planning Authority 2005) }\end{array}$ & NJTPA (32) & Active & Yes \\
\hline & 31. & Jurisdictions with current active local plans (Utah & UT (33) & Inactive & Yes \\
\hline & & Tomorrow Strategic Planning Committee 2003) & $\mathrm{NC}(34)$ & Active & No (required by law) \\
\hline & 32. & $\begin{array}{l}\text { Customer satisfaction with coordination (Missouri } \\
\text { Department of Transportation 2007) }\end{array}$ & $\mathrm{MO}(35)$ & Active & Yes \\
\hline & 33. & $\begin{array}{l}\text { Customer/stakeholder satisfaction rating (Wilbur Smith } \\
\text { Associates 2006) }\end{array}$ & MI (36) & Proposed & Yes \\
\hline & 34. & $\begin{array}{l}\text { Transportation projects are listed in regional } \\
\text { transportation plan (Cambridge Systematics, Inc. 2004) }\end{array}$ & $\mathrm{AZ}(37)$ & Active & $\mathrm{No}^{\mathrm{k}}$ \\
\hline
\end{tabular}


Table 1: Potential transportation/land use coordination performance measures at a glance.

\begin{tabular}{|c|c|c|c|c|c|}
\hline Goal & & Performance Measure & $\begin{array}{l}\text { State or } \\
\mathrm{MPO}^{\mathrm{ab}}\end{array}$ & Status ${ }^{c}$ & $\begin{array}{l}\text { Is data collected } \\
\text { explicity to measure } \\
\text { coordination? }^{\text {d }}\end{array}$ \\
\hline \multirow{9}{*}{$\begin{array}{l}\text { Reduce land } \\
\text { consumption } \\
\text { (and other } \\
\text { environmental } \\
\text { measures) }\end{array}$} & 35. & $\begin{array}{l}\text { Percentage of jobs or population in urban centers (North } \\
\text { Jersey Transportation Planning Authority 2005) }\end{array}$ & NJTPA (38) & Active & Yes \\
\hline & 36. & $\begin{array}{l}\text { Population density (North Jersey Transportation } \\
\text { Planning Authority 2005) }\end{array}$ & NJTPA (39) & Active & Yes \\
\hline & 37. & $\begin{array}{l}\text { Geographical expansion of urbanized area compared to } \\
\text { population growth rate (Rhode Island Statewide } \\
\text { Planning Program 2004) }\end{array}$ & $\mathrm{RI}^{\mathrm{I}}(40)$ & Proposed & Yes \\
\hline & 38. & $\begin{array}{l}\text { Conversion of undeveloped land (Minnesota } \\
\text { Department of Transportation 2003) }\end{array}$ & $\mathrm{MN}(41)$ & Inactive & Yes \\
\hline & 39. & $\begin{array}{l}\text { Loss of farmland, open space, habitat, forest land acreage } \\
\text { or loss of historic resources or of specified/designated } \\
\text { visual assets. }\end{array}$ & $\operatorname{ME}(42)$ & Proposed & Yes \\
\hline & 40. & Loss of wetlands & $\mathrm{CA}(43)$ & Proposed & Yes \\
\hline & \multirow[t]{3}{*}{41.} & \multirow{3}{*}{$\begin{array}{l}\text { Measured } \mathrm{O}_{3}, \mathrm{NO}_{x}, \mathrm{CO} \text {, and estimated (or measured) } \\
\mathrm{CO}_{2} \text { (Maryland Department of Transportation 2006; } \\
\text { Minnesota Department of Transportation 2003) }\end{array}$} & $\mathrm{MN}(44)$ & Not certain & No \\
\hline & & & $\mathrm{MD}(45)$ & Active & No \\
\hline & & & NY (46) & Active & Yes \\
\hline Total & \multicolumn{3}{|c|}{$\begin{array}{l}41 \text { different performance measures (or } 46 \text { applications of such measures) } \\
\text { inferred from states, MPOs, and literature }\end{array}$} & $\begin{array}{l}21 \text { Active } \\
\text { measures }\end{array}$ & 29 Yes measures \\
\hline
\end{tabular}

a State abbreviations: AZ (Arizona), California (CA), Florida (FL), Kansas (KS), Maryland (MD), Maine (ME), Michigan (MI), Minnesota (MN), Missouri (MO), New Hampshire (NH), New Mexico (NM), New York (NY), North Carolina (NC), Oregon (OR), Rhode Island (RI), Utah (UT), Vermont (VT), Washington (WA). Seven other states did not indicate specific performance measures for transportation/land use coordination, although some offered insights noted elsewhere: Arkansas, Illinois, Mississippi, New Jersey, Ohio, Oklahoma, and South Dakota.

b Metropolitan Planning Organization (MPO) abbreviations: NJTPA (North Jersey Transportation Planning Authority), TCMC (Twin Cities Metropolitan Council), WFRC (Wasatch Front Regional Council).

c Active (currently used), Proposed (considered for future use), Inactive (no longer used or being modified).

${ }^{\mathrm{d}}$ Yes (state or MPO uses metric to mark progress toward transportation/land use coordination); No (state or MPO does not necessarily use measure to measure progress toward such coordination).

e These performance measures are computed by measuring changes in mode of travel.

f This metric was listed under this goal because Maine indicated that it measures the ability to get from one destination to another readily.

$\mathrm{g}$ These performance measures are computed by measuring characteristics in addition to changes in travel mode.

h This metric is listed under this goal because the Twin Cities Metropolitan Council noted a policy of encouraging "growth and reinvestment in centers with convenient access to transportation corridors" (Metropolitan Council 2004).

i Oregon is piloting additional indices, such as a travel cost index based on the cost of traveling to a variety of destination types (e.g., employment, shopping, and recreational).

j Several additional performance measures for the Wasatch Front Regional Council were later provided, such as miles of new capacity projects potentially impacting historical neighborhoods.

k Arizona noted that this metric ensures that "transportation (and, indirectly, land use) decisions are consistent across different tiers of government" (Cambridge Systematics, Inc. 2004).

${ }_{1}$ Rhode Island later provided additional performance measures pertaining to mode split, transit, bike path construction, and emergency response (Rhode Island Statewide Planning Program 2006). 


\section{Goal convergence under the four scenarios}

The degree of consistency shown in Table 1 may be quantified by considering whether initiatives taken or influenced by a state DOT will tend to move the performance measures in a similar direction. For example, a state DOT may choose to expand freeways in congested areas where there is latent demand. If this latent demand is assumed to be strong, such that the increased demand does not significantly alter the level of congestion that existed prior to the expansion, then measure 5 in Table 1 (travel time to work) may be unaffected whereas measure 1 (percentage of commuters driving alone to work) should show a detrimental change (since more commuters will now be driving alone). In contrast, if this latent demand is assumed to be weak, such that the increased demand still reduces congestion overall, then measure 5 should show a beneficial change (since travel times will be reduced) whereas measure 1 should still show a detrimental change.

Under both assumptions concerning latent demand, the two performance measures are not consistent. A similar analysis may be applied across scenarios. For example, the highway expansion scenario just presented could be contrasted with a scenario of improving transit service. To the extent that both scenarios reduce congestion (at least in the short term), the two measures would be consistent across the two scenarios.

\subsection{Expected effects of the four scenarios on potential performance measures}

Table 2 shows the expected effects of the four scenarios defined previously on each performance measure listed in Table 1 .

As might be expected, some performance measure changes in Table 2 are speculative. For example, reducing transit costs might encourage infill development and thus reduce new exurban development along with highway construction and associated wetlands takings. Alternatively, reduced transit costs might encourage development along certain exurban corridors. A third possibility is that effects on land development might be small if the area already enjoyed high accessibility (Meyer and Miller 2001). Passing the cost reductions on to users in the form of increased service frequency would be expected to produce a larger effect than a simple reduction in fares to the extent that transit demand is more sensitive to service than cost (Sinha and Labi 2007).

To the extent that the data in Table 2 are accurate, an aggregate comparison of the scenarios initially suggests that some measures are preferable to others. In the extreme, Table 2 suggests that local autonomy should be increased and all locali- ties should be encouraged to increase transit subsidies. However, such a comparison presumes that each of the 41 measures shown in Table 2 carries equal weight among decision makers, which is likely not the case. In fact, some stakeholders might emphasize one or just a few of the metrics in Table 2 to the exclusion of all others. Further, if decision makers were presented with the four scenarios shown, it is quite possible that some constituents would support all four scenarios and that each scenario would attract at least some constituents. A more interesting comparison, therefore, is to examine consistency within the measures across each of the four scenarios.

For the 41 measures shown in Table 2, slightly less than onehalf (20) show a conflict among the four scenarios, where one scenario shows an increase in the performance measure and another shows a decrease. For example, the compact development scenario increases the metric defined as "percentage of commuters driving alone to work"; the reduced vehicular congestion scenario decreases the value of this measure. Reducing transit costs should decrease the measure "ratio of cost of non-auto travel to cost of auto travel," whereas reduced congestion should increase this ratio. Not all metrics result in a conflict in Table 2; e.g., access to centers should be improved whether one reduces vehicular congestion or transit costs, and there is no evidence that the other two scenarios (compact development and increased local autonomy) would reduce such access. The salient characteristic of Table 2, however, is that for almost one half of the metrics identified, a conflict is evident among at least two of the four scenarios-and each of the four scenarios could be viewed as a positive development by at least some stakeholders. The lack of conflict associated with the remaining measures does not guarantee consensus, as the effects are speculative. 
Table 2: Expected impact of the four scenarios on the performance measure.

\begin{tabular}{|c|c|c|c|c|c|}
\hline & Performance Measure & $\begin{array}{l}\text { Compact } \\
\text { Development }\end{array}$ & $\begin{array}{l}\text { Reduced } \\
\text { Vehicular } \\
\text { Congestion }\end{array}$ & $\begin{array}{l}\text { Reduced } \\
\text { Transit } \\
\text { Costs }\end{array}$ & $\begin{array}{l}\text { Increased } \\
\text { Local } \\
\text { Autonomy }\end{array}$ \\
\hline 1. & Percentage of commuters driving alone to work ${ }^{b}$ & Decrease & Increase & Decrease & Speculative \\
\hline 2. & Number of persons using other modes a & Increase & Decrease & Increase & Speculative \\
\hline 3. & Number of spaces used at park-and-ride facilities a & Speculative & Speculative & Increase & Speculative \\
\hline 4. & Vehicle miles traveled per capita ${ }^{b}$ & Decrease & Increase & Decrease & Speculative \\
\hline 5. & Travel time to work ${ }^{b}$ & Speculative & Decrease & Speculative & Speculative \\
\hline 6. & Travel distance to work ${ }^{\mathrm{b}}$ & Decrease & Increase & Speculative & Speculative \\
\hline 7. & Ability to get from one destination to another readily a & Increase & Increase & Increase & Speculative \\
\hline 8. & Percentage of housing units built by location type ${ }^{\text {a }}$ & Increase & Decrease & Speculative & Speculative \\
\hline 9. & Percentage of jobs/population within particular distance of transit a & Increase & Decrease & Increase & Speculative \\
\hline 10. & Miles of bike/ped facilities constructed ${ }^{a}$ & Increase & Decrease & Speculative & Speculative \\
\hline 11. & Number of routes designated as bicycle facilities a & Increase & Decrease & Speculative & Speculative \\
\hline 12. & Number of attractions within a threshold travel time ${ }^{a}$ & Speculative & Increase & Speculative & Speculative \\
\hline 13. & Ratio of cost of non-auto travel to cost of auto travel ${ }^{b}$ & Decrease & Increase & Decrease & Speculative \\
\hline 14. & Access to centers ${ }^{\text {a }}$ & Speculative & Increase & Increase & Speculative \\
\hline 15. & Ratio of jobs to housing a & Increase & Decrease & Speculative & Speculative \\
\hline 16. & Satisfaction with transportation options ${ }^{\text {a }}$ & Speculative & Speculative & Increase & Speculative \\
\hline 17. & Person-hours of delay ${ }^{b}$ & Speculative & Decrease & Speculative & Speculative \\
\hline 18. & Average [vehicle] delay per trip ${ }^{b}$ & Increase & Decrease & Decrease & Speculative \\
\hline 19. & Response time for fire, etc. ${ }^{b}$ & Speculative & Decrease & Speculative & Speculative \\
\hline 20. & Cost of above municipal services ${ }^{b}$ & Decrease & Increase & Speculative & Speculative \\
\hline 21. & Reduction in consumer costs attributable to better transport ${ }^{\mathrm{b}}$ & Increase & Decrease & Decrease & Speculative \\
\hline 22. & Ratio of actual corridor travel time to free flow travel time ${ }^{b}$ & Increase & Decrease & Speculative & Speculative \\
\hline 23. & $\begin{array}{l}\text { Number of jurisdictions that have adopted regulations protecting land } \\
\text { adjacent to airports from development }{ }^{\text {a }}\end{array}$ & Speculative & Speculative & Speculative & Speculative \\
\hline 24. & $\begin{array}{l}\text { Miles of roadway for which agreements are in place (between state DOT } \\
\text { and local government) a }\end{array}$ & Speculative & Speculative & Speculative & Speculative \\
\hline 25. & Alignment of strategic highway corridors and land use overlay a & Speculative & Speculative & Speculative & Speculative \\
\hline 26. & Arterials where an access management plan has been established ${ }^{a}$ & Speculative & Speculative & Speculative & Speculative \\
\hline
\end{tabular}


Table 2: Expected impact of the four scenarios on the performance measure.

\begin{tabular}{|c|c|c|c|c|c|}
\hline & Performance Measure & $\begin{array}{l}\text { Compact } \\
\text { Development }\end{array}$ & $\begin{array}{l}\text { Reduced } \\
\text { Vehicular } \\
\text { Congestion }\end{array}$ & $\begin{array}{l}\text { Reduced } \\
\text { Transit } \\
\text { Costs }\end{array}$ & $\begin{array}{l}\text { Increased } \\
\text { Local } \\
\text { Autonomy }\end{array}$ \\
\hline 27. & $\begin{array}{l}\text { Percentage of interregional corridor miles with corridor } \\
\text { management/land use plans a }\end{array}$ & Speculative & Speculative & Speculative & Increase \\
\hline 28. & Agreements between state and local plans ${ }^{a}$ & Speculative & Speculative & Speculative & Speculative \\
\hline 29. & Complete one corridor study per year ${ }^{a}$ & Speculative & Speculative & Speculative & Increase \\
\hline 30. & $\begin{array}{l}\text { Locations where state and integrated transportation studies are } \\
\text { undertaken a }\end{array}$ & Speculative & Speculative & Speculative & Increase \\
\hline 31. & Jurisdictions with current active local plans a & Speculative & Speculative & Speculative & Increase \\
\hline 32. & Customer satisfaction with coordination ${ }^{a}$ & Speculative & Speculative & Speculative & Increase \\
\hline 33. & Customer/Stakeholder satisfaction rating a & Speculative & Increase & Increase & Speculative \\
\hline 34. & Transportation projects are listed in the regional transportation plan ${ }^{a}$ & Speculative & Speculative & Speculative & Speculative \\
\hline 35. & Percentage of jobs or population in urban centers ${ }^{a}$ & Increase & Decrease & Speculative & Speculative \\
\hline 36. & Population density ${ }^{a}$ & Increase & Decrease & Speculative & Speculative \\
\hline 37. & Geographical expansion of the urbanized area ${ }^{a}$ & Decrease & Increase & Speculative & Speculative \\
\hline 38. & Conversion of undeveloped land ${ }^{\mathrm{b}}$ & Decrease & Increase & Speculative & Speculative \\
\hline 39. & Loss of farmland, open space, etc. ${ }^{b}$ & Decrease & Increase & Speculative & Speculative \\
\hline 40. & Loss of wetlands ${ }^{b}$ & Decrease & Increase & Speculative & Speculative \\
\hline 41. & Emissions (measured $\mathrm{O}_{3}, \mathrm{NO}_{x}, \mathrm{CO}$ and estimated [or measured] $\mathrm{CO}_{2}{ }^{\mathrm{b}}$ & Decrease & Increase & Decrease & Speculative \\
\hline \multicolumn{2}{|r|}{ Total number of cases where performance measure value increased } & 12 & 14 & 7 & 5 \\
\hline \multicolumn{2}{|c|}{ Total number of beneficial changes } & 19 & 5 & 12 & 5 \\
\hline \multicolumn{2}{|r|}{ Total number of detrimental changes } & 3 & 18 & 0 & 0 \\
\hline
\end{tabular}

a A beneficial change is one where the value of the performance measure increases.

${ }^{b}$ A beneficial change is one where the value of the performance measure decreases. 


\subsection{Limitations to determining the effects of scenarios on each performance measure}

The effects shown in Table 2 are based on the literature (Burchell et al. 2002; Parsons Brinckerhoff Quade \& Douglas, Inc. 1999) and on the researchers' judgment. The effects of each scenario on each metric are merely the "expected" impacts for several reasons. Each scenario may have unintended consequences; although (Parsons Brinckerhoff Quade \& Douglas, Inc. 1999) reported that compact development is generally expected to reduce demand for motorized travel, the same source noted that local conditions (e.g., differences in zoning policies) may cause variation in expected development impacts. Some effects are not immediate: changes in land development generally require more time than changes in motorists' route preferences (Parsons Brinckerhoff Quade \& Douglas, Inc. 1999). External influences, such as variations in fuel price and school quality, may also affect the impacts shown in Table 2 (Burchell et al. 2002).

Some assumptions were required to complete Table 2. Although a reduction in VMT will reduce emissions, trips made in urban areas tend to include more cold starts (due to less trip chaining) and lower speeds than trips in rural areas (Stone et al. 2007), both of which increase emissions. The assumption in Table 2 is that, consistent with the literature (Ewing et al. 2008), the emissions increase attributable to these two factors is exceeded by the reduction attributable to reduced VMT that would be seen in a compact area. Table 2 also assumes that the reduction in water and sewer costs that have been calculated for the case of compact development (Burchell et al. 2002) would extend to the case of provision of emergency medical services and schools. For the performance measure "reduction in consumer costs attributable to better transport," judgment was used; it could be argued that lower-cost transit systems would have no impact since many goods are transported by truck. However, reduction in the cost of transit for employees, whether manifested as a fare reduction or an increase in service levels, may still reduce the overall cost of goods, thus a "decreased" value in this performance measure is shown for this scenario.

Despite the authors' willingness to accept certain assumptions, the effects of changes in some performance measures are too variable to determine. For example, under the compact development scenario, the number of spaces used at a parkand-ride facility could increase (especially if clustered housing enabled residents to share auto trips to a central business district outside their local residential area) or the number of spaces at park-and-ride facilities could drop if compact development enabled more people to avoid auto-dependent modes altogether. Similarly, values for many of the performance measures related to aligning state and local efforts, such as customer satisfaction with coordination, are speculative for scenarios 1 and 2. A sudden decrease in congestion should improve customer satisfaction to the extent that congestion is a concern, but some customers might be more concerned with reduction in VMT, in which case customer satisfaction would not improve. For these situations, the value "speculative" is shown in Table 2.

\section{Discussion}

\subsection{Variation in performance measures}

The measures listed in Table 1 vary substantially across six attributes: (1) supporting data that comprise the metrics, (2) aspects of coordination emphasized by the metrics, (3) use of target values, (4) current status of the metrics, (5) terminology used in discussing the performance measures, and (6) geographical scope.

\section{Supporting data that comprise the metrics}

Ohio noted a distinction between measures based on (past) observed values and indicators based on (future) model outputs. Supporting data for these measures fall into three categories:

1. Observations of system performance. Examples include number of commuters traveling to work by various modes, amount of land consumed in a given year, and customer satisfaction with transportation options. These observations can be measured directly and do not require inference or judgment, except in terms of how the data are sampled or collected.

2. Information derived from models. A detailed example is a utility function that incorporates waiting time, travel time and out-of-pocket expenditures to determine a generalized cost for each mode of transportation, which can then be compared to the generalized cost of auto travel. Modeled emissions or VMT per person may also be placed in this category.

3. Administrative actions taken by relevant actors. An example is the Washington State DOT's technique of tracking airport land use compatibility by determining the number of jurisdictions that have adopted draft policies, formalized these policies, and formally adopted regulations 
protecting airport lands from encroachment by development (Washington State Department of Transportation 2006a).

In several cases, supporting data may be assigned to more than one category depending on resources available. For example, Florida stated that the number of miles of roadway for which signed agreements are in place between the state and the locale regarding access management (an observation of system performance) would be an ideal measure; however, because monitoring such an indicator might require significant resources, a starting point could be simply the number of development review meetings attended by state DOT staff (administrative actions).

\section{Aspects of coordination emphasized by the metrics}

Table 1 shows that different measures can accentuate different policy goals. Some clearly favor process over physical outcome. For example, Missouri noted that metrics are used "more directly for the coordination, much less so for the land use." In this vein, measures address agreement between government entities (or other stakeholders) ${ }^{1}$ rather than emphasizing a particular physical outcome such as Rhode Island's expansion of the urbanized area. A single indicator may even support multiple foci. For example, although California noted its long-range plan, which in turn emphasizes improved travel choices, it also noted that determining whether people can travel within a reasonable time to desired destinations might be used to determine the impact on equity.

As may be inferred from Table 1, measures may be established to assess intermediate steps or long-term objectives. New York stated that one goal of efficient land use is reduced person-hours of delay but also noted the possibility of developing intermediate goals. New Hampshire's indicator of percentage of interregional corridor miles with corridor management/land use plans might be one such intermediate goal. As an illustration of an area of emphasis, one view of transportation/land use coordination is the promotion of growth in desired locations. Table 3 shows the relative strengths and weaknesses of four metrics that may be used to quantify such growth. For example, although the first metric shown (percentage of built households by location types) can indicate the extent to which pristine land is protected, it may not reflect efforts that improve the quality of life in infill areas if such efforts do not affect the area's density.

\footnotetext{
${ }^{1}$ Levinson and Krizek (2008) refer to this as "process equity" to the extent it reflects equal inclusion in the planning process.
}

Use of target values

Most states surveyed did not set explicit targets for measures. Exceptions were New Mexico (designate 500 miles of bikeways annually); Vermont (construct more than four miles of bikeways annually); Washington (aim for 10 jurisdictions per year that adopt regulations protecting land adjacent to airports from development); and Rhode Island (allow the geographic size of the urbanized area to expand by no more than the population growth rate, which was forecast to be $2.5 \%$ in 2010 and $3.5 \%$ in 2020). To the extent that metrics should contrast the current and desired state of the system (Levinson and Krizek 2008), targets can provide a context for evaluation; for example, although it is generally desirable to minimize wetland loss, setting a target value based on previous years or current practice makes it possible to characterize acres of wetland lost (measure 40) as good or poor, and then to take action as appropriate.

\section{Current status of the metrics}

Some metrics have not been finalized because they have been initiated only recently. For example, the Wasatch Front Regional Council representative noted several possible indicators: ratio of jobs to housing, mix of residential and commercial uses, and whether a jurisdiction is implementing smart growth principles. Oregon's auto dependence index is being considered by one MPO on an experimental basis. Kansas is planning to identify metrics in addition to its metric of an annual per-person reduction in consumer costs (\$1297) attributable to interstate highways (Kansas Department of Transportation 2007). New York is planning to develop intermediate outcome measures related to the final goals of reduced auto congestion and reduced emissions. Finally, although Arizona currently has no explicit measures for transportation/land use coordination, it is conducting a study of transportation/land use coordination; the investigators were not tasked with developing measures, but the study results may suggest the development and application of measures.

Some metrics are evolving in response to policy changes. In the past, Minnesota has tracked the percentage of cities, towns and counties with plans that support state corridors. Supporting plans include grid networks to relieve arterial congestion or official maps of right-of-way the state will need. However, the state is considering moving in a different policy direction. Similarly, it appears that Utah's tracking of the number of counties with general plans (Utah Tomorrow Strategic Planning Committee 2003), has been discontinued. 
Table 3: Metrics that can be used to assess whether growth occurs in desired locations.
Performance Measure
Strength
Limitation

Percentage of built households by location type

Percentage of jobs within a certain distance of transit

Ratio of jobs to housing

Ratio of the cost of auto travel to non-auto travel
Captures location of new development

Focuses on the end result: Can individuals get to work?

Considers a basic need: Are employment opportunities and population growth matched?

Can help determine whether "desired locations" truly reduce transport costs
Only examines new growth and does not consider rehabilitation efforts in existing neighborhoods

By itself, does not diagnose whether obstacles relate to impedance or job opportunities

Influenced by other factors such as retirement population, job types, housing costs, and socioeconomic status

Good performance can be obtained through degradation of the auto mode (without improvement to non-auto modes)

Note: Other metrics that could be used include travel distance to work; ability to get from one destination to another readily; number of attractions within a threshold travel time; access to centers; percent of jobs or population in urban centers; agreement between state and local plans; and geographical expansion of urbanized area.

Other metrics are evolving because improvements are needed. For example, the North Jersey Transportation Planning Authority noted that per-capita VMT is the product of trip frequency and trip length, but that planners influence only the latter (through access to centers), leading the respondent to focus on measures that address access to various types of centers (e.g., jobs training centers, Medicaid facilities). Others have also noted that per-capita VMT is a weak measure because it may decline if either congestion or poverty grows (Reiff and Gregor 2005). Notably, the Oregon respondent commented that it is difficult to find measures that are both meaningful and readily explainable to the public.

\section{Terminology used in discussing the performance measures}

Two anecdotes from the survey suggested that the words chosen to describe performance measures can affect how those measures are received by different stakeholders. In Florida, for example, it was critical to differentiate between "corridor protection" and "corridor management" when communicating with localities;. "corridor protection" had a negative connotation of state efforts to acquire inexpensive right-of-way and "corridor management" had a more positive connotation of either minimizing additional corridor access points or max- imizing coordination with local governments with regard to adjacent traffic generators. In addition, the fact that several respondents noted that these metrics may be computed by some other entity (e.g., the California Environmental Protection Agency rather than Caltrans may track the number of wetlands) highlights the importance of using terminology that is equally acceptable to different agencies.

\section{Geographical scope}

Most measures in Table 1 may be applied at the state, regional or jurisdictional level. However, three observations suggest that the state's role may be one of supporting regions in the computation of these measures rather than setting a statewide target.

1. In three of the states indicated in Table 1 , an answer was provided because of the state DOT's links with an MPO or state land use agency. In only one case did the respondent note that the indicator measures transportation/land use coordination and that a target value had been set. The indicator was given by a state (Rhode Island) planning agency, not the state DOT. 
2. Respondents from three states (Arkansas, Michigan and South Dakota) noted that their states do not control land development. Any policy goal of transportation/land use coordination must recognize the legal environment in which such goals may be achieved (Michigan Department of Transportation and Wilbur Smith Associates 2006) which in Michigan referred to home rule and property rights.

3. The key value for a particular measure-jobs/housing balance-may be intrinsically regional. It was noted at a meeting of a planning commission in the Washington, D.C. region (Transportation Accountability Commission 2007) that a jobs/housing balance of 1.6 was a useful threshold for the Washington, DC, region. A value higher than 1.6 would indicate that the region is importing workers (McClain and Fuller 2003; Transportation Accountability Commission 2007) from localities outside the Washington, D.C., region-and thus contributing to the need for longer commutes. The implication was that a value of 1.6 or below might mean the workers would not have to live outside the region and thus presumably commutes would be shortened and development at the periphery of the region would be lessened. This value of 1.6 depends on both the characteristics of the region and where the boundary of the region is placed. For example, in another location, a jobs/housing average ratio of 1.25 was noted (Singa et al. 2004), suggesting a different threshold value than that for Washington, DC. This observation supports comments made at the meeting that some measures may be appropriate at the regional rather than the state level (Transportation Accountability Commission 2007).

\subsection{Commonality in performance measures for states}

Although the measures in Table 1 show substantial variation, two trends are evident for states. First, metrics are more likely to be active if they rely on data traditionally collected by states. Excluding MPOs, 39 performance measure applications were suggested, with 16 (41\%) being active. Not surprisingly, 10 of these relate to three goals closest to the historical mission of state DOTs and thus rely on data states are likely to collect: increase transportation options (based on measuring changes in modal split), improve the quality of these options, and align state and local efforts. (Alternatively, the ratios of active to proposed metrics for these goals were $67 \%, 100 \%$, and $60 \%$, respectively.) By contrast, for the two goals of improving public services/economic growth and protecting/managing corri- dors, supporting measures rely on local land use data that are often not collected by states; thus, only one of the 11 proposed measures in these areas was active (9\%).

Second, the metrics are influenced by factors other than vehicular congestion. In fact, when the 23 metrics that states established explicitly to assess transportation/land use coordination are considered, an improved score would likely be evident in only seven of the metrics if a state were suddenly able to move all vehicular traffic at free flow speeds. (e.g., response times for EMS or ratio of corridor travel time to free flow travel time.) Poorer scores would likely result for eight of the metrics, (e.g., the ratio of non-auto travel cost to auto travel cost). For another eight metrics (e.g., the number of jurisdictions with active regional plans), it is not possible to determine how the elimination of congestion would affect the metric.

\subsection{Consistency among the performance measures for diverse scenarios}

A straightforward lesson drawn from this discussion is that transportation/land use coordination measures at the state level have not fully matured. As evidence, one could note that transportation/land use coordination requires a multifaceted perspective, yet each metric in Table 1 reflects, by itself, just one of several necessary dimensions of performance. For example, the metric "customer satisfaction" reflects-in part - the quality-of-life dimension, but not necessarily the resource conservation or financial dimensions noted by Sinha and Labi (2007) (which could be captured by the loss of farmland metric or the reduction in consumer cost metric, respectively). Alternatively, this customer satisfaction metric reflects the experiential dimension but not necessarily the equity, expedience, environmental and efficiency dimensions outlined by Levinson and Krizek (2008), the last of which is partly addressed by the "conversion of undeveloped land" metric. Further, some of this paper's findings address concerns raised in the survey, e.g. incentives for coordination (Armstrong et al. 2001; Courchesne 2004) may merit exploration given a state's lack of land use authority.

It is possible, however, to draw a more nuanced inference that may prove useful for future endeavors. No measure intrinsically represents transportation/land use coordination at the state level because, as shown by the results in Table 1 , the scope of such coordination broadens when efforts are made to define associated measures. This observation is contrary to other areas where measures have been developed; for example, if a group of stakeholders were asked to identify measures for congestion, the discussion of specific measures, such as person hours of delay, delay per trip, or travel speed (Falcocchio 
2004), would narrow the scope of what is meant by "congestion." Similarly, in the safety area, stakeholders have generally converged on measures related to injury crashes, thereby clarifying what is meant by "safety." The convergence in these areas is fundamentally different from the divergence of performance measures for the areas of "transportation/land use coordination."

The composite measures suggested in the literature had a unifying theme: not transportation/land use coordination but rather a specific outcome, such as sustainability (based on indicators for air quality, oil and land consumption, etc.) (Lautso et al. 2004), or availability of multiple transportation options (based on indicators for parking availability, block size, and so forth) (Moudon et al. 2005; Washington State Department of Transportation 2006c), or quality of life (Doi et al. 2008). The performance measures in Table 1 do not appear to have a definitive overarching framework. For example, a reduction in consumer costs attributable to better transportation is not necessarily consistent with reductions in land consumption. Thus, although additional research to identify performance measures (including composite metrics) will provide insights into how transportation/land use coordination may be assessed, analysis of the information presented in Table 1 suggests that the current lack of agreement regarding the goal of such coordination may impede the determination of appropriate measures. These findings echo the statement by (Hartgen and Neumann 2002) that "clarity of objectives" is key to implementing performance measures. While objectives are clear in some contexts, such as private enterprise, they are often much less clear with respect to transportation/land use coordination; (Levinson and Krizek 2008) noted that a "loftier" question is whether there is agreement regarding a desired pattern of land development.

\section{Conclusions}

The central finding of this paper is that the performance measures identified do not converge toward a single goal. A quick examination of the measures shows that they may be linked with seven different goals, as shown in Table 1. A more detailed testing with different policy scenarios, as shown in Table 2, indicates that there is no single overarching goal for these measures. For example, just eleven of the metrics appear to measure directly whether growth occurs in desired locations, as shown in Table 3. When a particular goal favored by some constituencies is sought, such as aligning state and local efforts, some metrics linked with that goal will be improved whereas others will not. On the basis of this finding, five discrete conclusions can be made:

1. The development of performance measures to support goals for transportation/land use coordination may increase conflicts among stakeholders. For example, a scenario that led to increased compact development might improve performance for some measures (e.g., geographical expansion of the urbanized area) but hurt performance for others (e.g., ratio of actual corridor travel time to free flow travel time). When four scenarios (compact development, reduced vehicular congestion, reduced transit costs, and increased local autonomy) were considered, 20 of 41 performance measures tested showed a probable conflict, with one or more of the indicators improving and one or more worsening. Thus, there does not appear to be agreement on a particular metric that best reflects transportation/land use coordination. This stands in contrast to findings from the domains of safety and maintenance, where the development of performance measures generally decreases stakeholder conflicts (California Department of Transportation 2006).

2. The goals to be achieved as a result of transportation/land use coordination differ substantially from state to state. Goals cited by 11 states that had established explicit transportation/land use performance measures included increased transportation modal options, improved quality of these options, better access management, reduced land consumption, increased harmony between state and local governments, and better air quality.

3. Transportation/land use coordination is not a goal unto itself but rather a means to achieve a larger goal. For example, although several states noted that the improvement of air quality was a measure of transportation/land use coordination, air quality may be improved through a variety of mechanisms other than transportation/land use coordination. If the language of outputs and outcomes, rather than measures, were applied to goals, then transportation/land use coordination would be an output goal. It is recognized that multiple dimensions of performance necessitate the use of multiple performance measures in general (Sinha and Labi 2007) and for transportation/land use coordination in particular (Levinson and Krizek 2008), but the findings herein do not suggest agreement among stakeholders-yet. 
4. A wide range of potential transportation/land use coordination indicators exists. Of the 41 metrics in this study, some are based on observed data, some are based on models, and some are based on processes rather than physical outcomes. Even in support of a single goal, many indicators may be used, reflecting the fact that different indicators are tailored to different types of available data.

5. A majority of responding states do not explicitly measure transportation/land use coordination at the state level. Of the 25 states from which a response was received, only 11 had an explicit indicator in that regard, and for eight of these, the indicators were either discontinued or under development, leaving only three states with an active, explicit metric at the state level. These states were Missouri (customer satisfaction), Oregon (attractions within a threshold travel time), and New York (person-hours of delay and quantity of emissions).

\section{Acknowledgments}

This work could not have been accomplished without the help of the following individuals who took the time to provide indicators, offer insights, or suggest additional contacts: Brent Barnes (New Jersey DOT), Wayne Bennion (Wasatch Front Regional Council), Lynne Bly (Minnesota DOT), Robby Burt (Mississippi DOT), Deva Deka (North Jersey Transportation Planning Authority), Stephen Devine (Rhode Island DOT), Tremain Downey (Caltrans), Kathy Fuller (Maine DOT), Susan Gorski (Michigan DOT), Brian Gregor (Oregon DOT), Ahmad Jaber (Utah DOT), Connie Kozlack (Twin Cities Metropolitan Council), Dianne Kresich (Arizona DOT), Nick Mandel (New Mexico DOT), Alan Matheson (Envision Utah), Clint McCarthy (Washington State DOT), Leslie Nunes (Illinois DOT), Patricia Oliver-Wright (New Mexico DOT), Jerry Ortbahn (South Dakota DOT), Ernest Perry (Missouri DOT), Virginia Porta (Arkansas DOT), Bart Selle (Vermont Agency of Transportation), Freddie Simmons (Kansas DOT), Janine Simonsen (New York DOT), Gary Sokolow (Florida DOT), Ron Spalding (Maryland DOT), Kimberly Spence (Virginia DOT), Dawn Sullivan (Oklahoma DOT), Dan Thomas (North Carolina DOT), Mary Lynn Tischer (Virginia DOT), Jennifer Townley (Ohio DOT), Katherine Trapani (Rhode Island Statewide Planning), and Bill Watson (New Hampshire DOT). The authors also acknowledge the helpful comments of reviewers for the Journal of Transport and Land Use. In- clusion of a name or organization does not indicate agreement with this paper; the authors alone are responsible for errors.

\section{References}

Amekudzi, A., L. Thomas-Mobley, and C. Ross. 2007. Transportation planning and infrastructure delivery in major cities and megacities. Transportation Research Record, pp. 17-23. doi: 10.3141/1997-03.

American Association of State Highway and Transportation Officials. 2009. Center for environmental excellence: Land use case studies. URL http://environment.transportation. org/environmental_issues/land_use_sg/case_studies.aspx.

Armstrong, M., B. Sears, and F. Wen. 2001. The new economy and Jobs/Housing balance in southern california. Technical report, Southern California Association of Governments, Los Angeles, CA. URL http://www.scag.ca.gov/Housing/ pdfs/Balance.pdf.

Atlanta Regional Commission. 2002. Community choices quality growth toolkit: Jobs-housing balance. Technical report, Atlanta Regional Commission. URL www. atlantaregional.com/.../gs_cct_jobshousingtool_1109.pdf. Avery, K., J. Vankerhove, M. Wyckoff, and T. Zwahlen. 2006. Proactive noise avoidance and mitigation measures. Executive Summary SD-2005-06-X, Bergman Associates and Planning and Zoning Center, Inc. for South Dakota Department of Transportation, Office of Research. URL http://apps.sd.gov/Applications/ HR19ResearchProjects/Projects\%5CSD2005_06_X.pdf.

Burchell, R., G. Lowenstein, W. Dolphin, C. Galley, A. Downs, S. Seskin, K. Still, and T. Moore. 2002. TCRP report 74: Costs of sprawl-2000. Technical report, Transportation Research Board, Washington, DC. URL http://www.trb.org/Main/Blurbs/160966.aspxandhttp: //www.worldtransitresearch.info/research/3006/.

California Department of Housing and Community Development. 2007. California’s jobs-housing balance incentive grant program: Final report to the Legislature. Technical report, California Department of Housing and Community Development. URL http://www.hcd.ca.gov/fa/jhbig/ jhb_rept_legis1007.pdf.

California Department of Transportation. 2006. California transportation plan 2025. Technical report, California Department of Transportation, Sacramento, CA. URL http://www.dot.ca.gov/hq/tpp/ offices/osp/ctp2025_files/CTP_2006.pdfandhttp: //www.dot.ca.gov/hq/tpp/offices/osp/ctp2025.html. 
Cambridge Systematics, Inc. 2004. MoveAZ: long range transportation plan. Technical report, Arizona Department of Transportation, Phoenix. URL http://azmemory.lib.az.us/cdm4/item_viewer.php? CISOROOT $=/$ statepubs\&CISOPTR $=2460 \&$ REC $=5$.

Cervero, R. 1996. Jobs-housing balance revisited: Trends and impacts in the San Francisco Bay area. Journal of the American Planning Association, 62(4):492-511. doi: $10.1080 / 01944369608975714$.

Courchesne, C. 2004. What regional agenda? reconciling massachusetts' affordable housing law and environmental protection. Harvard Environmental Law Review, 28(1):215-247. URL http://www.law.harvard.edu/ students/orgs/elr/older.php\#volume28_1.

Doi, K., M. Kii, and H. Nakanishi. 2008. An integrated evaluation method of accessibility, quality of life, and social interaction. Environment and Planning B: Planning and Design, 35(6):1098-1116. doi: 10.1068/b3315t.

Duthie, J., K. Cervenka, and S. Waller. 2007. Environmental justice analysis: Challenges for metropolitan transportation planning. Transportation Research Record, 2013:8-12. doi: $10.3141 / 2013-02$.

El-Geneidy, A. and D. Levinson. 2006. Access to destinations: Development of accessibility measures. Technical report, Minnesota Department of Transportation and University of Minnesota Center for Transportation Studies. URL http://www.cts.umn.edu/Publications/ ResearchReports/reportdetail.html?id=1072.

Ewing, R. 1993. Transportation service standards-as if people matter. Transportation Research Record, 1400:10-17. URL http://pubsindex.trb.org/view.aspx?id=383258.

Ewing, R., K. Bartholomew, S. Winkelman, J. Walters, and D. Chen. 2008. Growing Cooler: The Evidence on Urban Development and Climate Change. Washington, DC: Urban Land Institute. URL http://www.uli.org/News/PressReleases/Archives/ 2008/2008PressRelease/Growing\%20Cooler.aspx.

Falcocchio, J. 2004. Performance measures for evaluating transportation systems. Transportation Research Record, 1895:220-227. doi: 10.3141/1895-27.

Guttenplan, M., B. Davis, R. Steiner, and D. Miller. 2003. Planning-level areawide multimodal level-of-service analysis: Performance measures for congestion management. Transportation Research Record, 1858:61-68. doi: 10.3141/1858-09.

Handy, S. 2005. Planning for accessibility, in theory and in practice. In D. Levinson and K. Krizek, eds., Access to Destinations, pp. 131-147. Oxford: Elsevier.
Harris, B. 2001. Accessibility: Concepts and applications. Journal of Transportation and Statistics, 4((2/3)):15-30. URL http://www.bts.gov/publications/journal_of_ transportation_and_statistics/volume_04_number_23/.

Hartgen, D. and L. Neumann. 2002. Performance: A TQ point/counterpoint exchange with David T. Hartgen and Lance A. Neumann. Transportation Quarterly, 56(1):5-19. URL http://trid.trb.org/view.aspx?id=708292.

Horner, M. and J. Mefford. 2005. Examining the spatial and social variation in employment accessibility: A case study of bus transit in Austin, Texas. In D. Levinson and K. Krizek, eds., Access to Destinations, pp. 193-214. Oxford: Elsevier.

Kaine, T. 2006. Executive Order 37: Creating the Transportation Accountability Commission. Published: Office of the Governor, Richmond, VA, URL http://www.vtrans. org/transportation_accountability_commission.asp.

Kansas Department of Transportation. 2007. Kansas making progress: Our transportation performance 2007 annual report. Technical report, Kansas Department of Transportation. URL www.ksdot.org/PDF_Files/ KDOTReport01-22-07Final.pdf.

Knack, R. 2007. Land use and transportation: You can't have one without the other. Planning, 73(5):34-36. URL http: //trid.trb.org/view.aspx?id=809384.

Koski, R. 1992. Bus transit. In G. Gray and L. Hoel, eds., Public Transportation, pp. 148-176. Englewood Cliffs, NJ: Prentice Hall, 2nd edition.

Krizek, K. 2005. Perspectives on accessibility and travel. In D. Levinson and K. Krizek, eds., Access to Destinations, pp. 109-130. Oxford: Elsevier.

Larson, M. 2005. Organizing for performance management. In TRB Conference Proceedings 36: Performance Measures to Improve Transportation Systems, pp. 99-120. Washington, DC: Transportation Research Board.

Lautso, K., K. Spiekermann, M. Wegener, I. Sheppard, P. Steadman, A. Martino, R. Domingo, and S. Gayda. 2004. PROPOLIS: planning and research of policies for land use and transport for increasing urban sustainability. Technical report, European Commission. URL http://www.ltcon.fi/ propolis/.

Lave, C. 2006. Love, lies, and transportation in LA, again: An updated almanac in honor of Mel Webber. Access, pp. 40-41. URL www.uctc.net/news/ melwebberaccessspecialissue.pdf.

Levine, J. 1998. Rethinking accessibility and jobs-housing balance. Journal of the American Planning Association, 64(2):133-149. doi: 10.1080/01944369808975972. 
Levinson, D. and K. Krizek. 2008. Planning for Place and Plexus: Metropolitan Land Use and Transport. New York: Routledge.

Levy, J. 1994. Contemporary Urban Planning. Englewood Cliffs, NJ: Prentice-Hall.

Lewis, R., G. Knaap, and J. Sohn. 2009. Managing growth with priority funding areas: A good idea whose time has yet to come. Journal of the American Planning Association, 75(4):457-478. doi: 10.1080/01944360903192560.

Maryland Department of Transportation. 2006. 2006 annual attainment report on transportation system performance. Technical report, Maryland Department of Transportation. URL http://www.marylandtransportation.com/Planning/ Plans\%20Programs\%20Reports/Reports/Attainment\% 20Reports/2006\%20Attainment\%20Report.pdf.

McClain, J. and S. Fuller. 2003. Future housing supply and demand analysis for the greater Washington area. Technical report, Center for Regional Analysis, School of Public Policy, George Mason University, Fairfax, VA.

Metropolitan Council. 2004. Accommodating regional growth. In 2030 Transportation Policy Plan, pp. 1-6. Saint Paul, MN: Metropolitan Council (Minnesota). URL http://www.metrocouncil.org/planning/transportation/ TPP/2004/TPP04Chapter1_Final.pdf.

Metropolitan Council.2006. Department results (Metropolitan Council). URL http://departmentresults.state.mn.us/ met/index.html.

Meyer, M. 2005. Use of performance measures for surface transportation in different institutional and cultural contexts: Cases of Australia, Japan, and New Zealand. Transportation Research Record, 1924:163-174. doi: 10.3141/1924-21.

Meyer, M. and E. Miller. 2001. Urban Transportation Planning: A Decision-Oriented Approach. McGraw-Hill series in transportation. Boston: McGraw-Hill, 2nd edition.

Michigan Department of Transportation and Wilbur Smith Associates. 2006. MDOT state long-range transportation plan 2005-2030: Land use technical report. Technical report, Michigan Department of Transportation. URL http://www.michigan.gov/documents/mdot/MDOT_ SLRP_TR_Land_Use_11-30-06_179791_7.pdf.

Minnesota Department of Transportation. 2003. 2003 statewide transportation plan. Technical report, Minnesota Department of Transportation, St. Paul.

Missouri Department of Transportation. 2007. MoDOT Tracker. URL http://www.modot.mo.gov/about/general_ info/Tracker.htm.
Moudon, A., S. Kavage, J. Mabry, and D. Sohn. 2005. A transportation-efficient land use mapping index. Transportation Research Record, 1902:134-144. doi: 10.3141/1902-16.

New Jersey State Planning Commission. 2001. State development and redevelopment plan. URL www.nj.gov/state/ planning/plan.html.

North Jersey Transportation Planning Authority. 2005. Access and Mobility 2030: Regional Transportation Plan. Published: Web site, URL http://www.njtpa.org/Pub/ Report/LRP/Default.aspx.

Orski, C. 2009. The unfulfilled promise of Maryland's smart growth policy. Innovation Briefs, 20(21). URL http:// www.innobriefs.com/abstracts/index.html.

Parsons Brinckerhoff Quade \& Douglas, Inc. 1999. Land use impacts of transportation: A guidebook. NCHRP report 423A, Transportation Research Board, Washington, DC. URL http://trid.trb.org/view.aspx?type=MO\&id= 498620.

Pawlovich, M., R. Souleyrette, and T. Strauss. 1998. A methodology for studying crash dependence on demographic and socioeconomic data. In Crossroads 2000 Proceedings, pp. 209-215. Iowa State University. URL http: //www.ctre.iastate.edu/pubs/crossroads/209method.pdf.

Peng, Z. 1997. The jobs-housing balance and urban commuting. Urban Studies, 34(8):1215-1235. doi: 10.1080/0042098975600. URL http://usj.sagepub.com/ content/34/8/1215.abstract.

Reiff, B. and B. Gregor. 2005. Transportation planning performance measures. Final Report SPR 357, Oregon Department of Transportation. URL http://www.oregon.gov/ODOT/TD/TP_RES/docs/ Reports/PlanningPerformanceMeasures.pdf.

Rhode Island Statewide Planning Program. 2004. Transportation 2025: Recommendations. Technical report, State of Rhode Island and Providence Plantations. URL http: //www.planning.ri.gov/transportation/recommend.pdf.

Rhode Island Statewide Planning Program. 2006. Performance evaluation: Transportation 2025 (2004). Technical report, Rhode Island Statewide Planning Program. URL http://www.planning.ri.gov/transportation/perfeval.pdf.

Shaheen, S., A. Schwartz, and K. Wipyewski. 2004. Policy considerations for carsharing and station cars: Monitoring growth, trends, and overall impacts. Transportation Research Record, 1887:128-136. doi: 10.3141/1887-15.

Singa, K., R. Hutabarat, and M. Chou. 2004. Growth visioning for the westside cities of Los Angeles County, California: Land use and transportation factors influencing con- 
gestion and jobs-housing imbalances. Transportation Research Record, 1895:8-14. doi: 10.3141/1895-02.

Sinha, K. and S. Labi. 2007. Transportation Decision Making: Principles of Project Evaluation and Programming. Hoboken, NJ: John Wiley.

Staley, S. and E. Claeys. 2005. Is the future of development regulation based in the past? toward a marketoriented, innovation friendly framework. Journal of Urban Planning and Development, 131(4):202-213. doi: 10.1061/(ASCE)0733-9488.

Stone, B., A. Mednick, T. Holloway, and S. N. Spak. 2007. Is compact growth good for air quality? Journal of the American Planning Association, 73(4):404-418. doi: 10.1080/01944360708978521.

Transportation Accountability Commission. 2007. Draft minutes of the transportation accountability commission, outcome measures subcommittee meeting [Held] may 16, 2007. Published: Meeting minutes, URL http://www.ctb. virginia.gov/ctb-meeting-archive-2007.asp.

Utah Tomorrow Strategic Planning Committee. 2003. Utah tomorrow strategic plan. Technical report, Utah Tomorrow Strategic Planning Committee, Salt Lake City. URL http://www.le.utah.gov/documents/utahtomorrow/ utahtomorrow.pdf.

Vanka, S., S. Handy, and K. Kockelman. 2005. State-Local coordination in managing land use and transportation along state highways. Journal of Urban Planning and Development, 131(1):10-18. doi: 10.1061/(ASCE)0733-9488.

Venner Consulting and Parsons Brinckerhoff. 2004. Environmental stewardship practices, procedures, and policies for highway construction and maintenance. Technical report, American Association of State Highway and Transportation Officials, Standing Committee on the Environment. URL http://onlinepubs.trb.org/onlinepubs/ archive/NotesDocs/25-25(4)_FR.pdf.

Vermont Agency of Transportation. 2007. Performance measures. Technical report, Vermont Agency of Transportation, Montpelier.

Virginia Department of Transportation. 2008. Chapter 155: Traffic impact analysis regulations. URL http://www.virginiadot.org/projects/resources/ 2008Ch155TIARegs7.21.08.pdf.

Virginia Department of Transportation. 2010. Revised traffic impact analysis regulations administrative guidelines. Technical Report 24VAC30-155, Land Development Section, Transportation and Mobility Planning Division, Virginia Department of Transportation. URL http://www.virginiadot.org/projects/resources/
ADMINISTRATIVE_GUIDELINES_TIA_REGS_7. 2008.doc.

Waddell, P., G. Ulfarsson, J. Franklin, and J. Lobb. 2007. Incorporating land use in metropolitan transportation planning. Transportation Research Part A, 41(5):382-410. doi: 10.1016/j.tra.2006.09.008.

Washington State Department of Transportation. 2006a. Measures, markers and mileposts: The gray notebook, edition 21. Quarterly report, Washington State Department of Transportation. URL http://www.wsdot.wa.gov/NR/rdonlyres/ DED9359C-E217-4880-9F84-CC3A3CF622B0/0/ GrayNotebookMar06.pdf.

Washington State Department of Transportation. 2006b. Measures, markers and mileposts: The gray notebook, edition 23. Technical report, Washington State Department of Transportation. URL http://www.wsdot.wa.gov/NR/rdonlyres/ 03C73B90-7E2B-45BA-945D-46CBF72A8010/0/ GrayNotebookSep06.pdf.

Washington State Department of Transportation. 2006c. Research notes: Transportation-Efficient land use mapping index TELUMI). Technical report, Washington State Department of Transportation. URL http://www.wsdot.wa.gov/NR/rdonlyres/ C62FF2BC-8C96-46A9-84FD-AAD314376A48/0/ ResearchNotesTELUMI_W.pdf.

Wilbur Smith Associates. 2006. MDOT state long-range transportation plan 2005-2030: Goals, objectives, and performance measures report. Technical report, Michigan Department of Transportation. URL http://www.michigan.gov/documents/mdot/MDOT_ SLRP_rept_Goals_Objectives_Performance_Report_ 11-17-061_180916_7.pdf.

Zemotel, L. and D. Montebello. 2002. Interregional corridors: Prioritizing and managing critical connections between Minnesota's economic centers. Transportation Research Record, 1817:79-87. doi: 10.3141/1817-10. 